\title{
DNA methyltransferases $3 a$ and $3 b$ are differentially expressed in the early stages of a rat liver carcinogenesis model
}

\author{
CARLOS ALBERTO VALENCIA ANTÚNEZ ${ }^{1}$, LUCÍA TAJA CHAYEB ${ }^{3}$, MIGUEL ÁNGEL RODRÍGUEZ-SEGURA ${ }^{2}$, \\ GUADALUPE SOLEDAD LÓPEZ ÁLVAREZ ${ }^{1}$, CLAUDIA M. GARCÍA-CUÉLLAR ${ }^{3}$ and SAÚL VILLA TREVIÑO ${ }^{1}$
}

\author{
Departments of ${ }^{1}$ Cell Biology and ${ }^{2}$ Physics, Center for Research and Advanced Studies (CINVESTAV) IPN, \\ ${ }^{3}$ National Cancer Institute, Basic Research Branch, Mexico, D.F., Mexico
}

Received May 15, 2014; Accepted July 23, 2014

DOI: $10.3892 / o r .2014 .3462$

\begin{abstract}
Carcinogenesis is driven by the accumulation of mutations and abnormal DNA methylation patterns, particularly the hypermethylation of tumor-suppressor genes. Changes in genomic DNA methylation patterns are established by the DNA methyltransferases (DNMTs) family: DNMT1, DNMT3a and DNMT3b. The DNMTs are known to be overexpressed in tumors. However, when the DNMTs expression profile is altered in earlier stages of carcinogenesis remains to be elucidated. The resistant hepatocyte model (RHM) allows the analysis of the hepatocellular carcinoma (HCC) from the formation of altered cell foci to the appearance of tumors in rats. To investigate the DNMTs expression in this model, we first observed that timp3, rassfla and pl6 genes became methylated during cancer development by methylation-specific PCR (MSP) and the bisulphate sequencing PCR (BSP) of timp3. The differential expression at the RNA and protein level of the three DNMTs was also assessed. dnmt1 expression was higher in tumors than in normal and early cancer stages. However, no evident
\end{abstract}

Correspondence to: Dr Saúl Villa Treviño, Departamento de Biología Celular, Centro de Investigación y de Estudios Avanzados (CINVESTAV) Av. IPN No. 2508, Postal Code 07360, Mexico, D.F., Mexico

E-mail: svilla@cell.cinvestav.mx

Abbreviations: DNMT(s), DNA methyltransferase(s); RHM, resistant hepatocyte model; HCC, hepatocellular carcinoma; MSP, methylation-specific PCR; BSP, bisulphite sequencing PCR; AHF, altered hepatocyte foci; GGT, g-glutamil transpeptidase; NT, non-treated sample; DEN, $24 \mathrm{~h}$ after diethylnitrosamine administration; 2AAF, $24 \mathrm{~h}$ after 2-acetylaminofluorene administration; $\mathrm{PH}, 24 \mathrm{~h}$ after partial hepatectomy; $16 \mathrm{D}, 16$ days after complete carcinogenic treatment; $1 \mathrm{M}, 1$ month after complete carcinogenic treatment; $5 \mathrm{M}$, 5 months after complete carcinogenic treatment; $12 \mathrm{M}, 12$ months after complete carcinogenic treatment

Key words: cancer, hepatocellular carcinoma, initiation, promotion, progression, preneoplastic lesions, tumors, resistant hepatocyte model, DNA methyltransferases, expression profile overexpression of the enzyme was identified by immunohistochemistry. By contrast, DNMT3a and DNMT3b were consistently subexpressed in tumors. In the present study, we report a carcinogenesis model that does not feature the overexpression of DNMT1 but exhibits a transient expression of DNMT3a and DNMT3b.

\section{Introduction}

Cytosine methylation is an epigenetic function involved in the control of the gene expression of eukaryotic cells. In mammalian cells, $\sim 3-5 \%$ of the cytosine residues in genomic DNA are methylated, 70-80\% of which are found in $\mathrm{CpG}$ dinucleotiderich regions known as $\mathrm{CpG}$ islands (1-5). In normal cells, $\mathrm{CpG}$ methylation patterns in genomes are established and maintained precisely after DNA replication via the action of the DNA methyltransferases (DNMT) (4-7). However, cancer cells have two contrasting features: genome-wide hypomethylation and specific $\mathrm{CpG}$ island hypermethylation (7-9). It is also known that hypermethylation of tumor-suppressor genes causes inactivation and facilitates gene mutation associated with allelic loss $(1,7,10)$.

The enzymatic methylation machinery is composed of catalytically active DNMTs, including DNMT1, DNMT3a and DNMT3b. DNMT1 is the most abundant DNMT and has preference for hemimethylated DNA substrates. It is responsible for copying the methylation pattern after each round of DNA replication $(6,11)$. DNMT3a and DNMT3b (also known as de novo methytransferases) target unmethylated DNA and are essential for embryonic development $(6,11,12)$. Increased mRNA and protein expression levels of the three DNMTs have been reported in the majority of human cancers $(7,11,13$ 15). It is commonly described that the hypermethylation of tumor-suppressor genes correlates with a higher expressiono of DNMTs $(1,9,12)$. We hypothesized that the overexpression of the enzymes is an early event that precedes the appearance of preneoplastic lesions and tumors. Deleterious mutations in DNMT1 or DNMT3b have not been described thus far in human tumors (16). Although deleterious mutations in DNMT3a are not common in cancer, they have been associated with poor prognosis (17). To gain insight into the specific contribution of each DNMT to carcinogenesis, several animal models have been studied in the absence of one of the 
methyltransferases with contrasting results. In murine models, it has been shown that heterozygous mutations for DNMT1 caused a global reduction in DNA methylation and a decrease in the development of intestinal tumors, while simultaneously enhancing lymphomagenesis (18). It has also been reported that deletion of DNMT3a in a K-ras-dependent murine lung cancer model, promoted tumor progression (16), whereas the loss of DNMT3b accelerated the lymphomagenesis in a murine model of MYC-induced cancer $(18,19)$.

Animal models also allow the analysis of stages prior to tumor formation. The early stages of carcinogenesis are characterized by the presence of altered cells foci or preneoplastic lesions $(20,21)$. Although the analysis of these lesions are potentially useful for the identification of early genetic and epigenetic events leading to cancer in human beings, such dysplastic nodules are difficult to detect in biopsies and commonly coexist with other tissue pathologies (20). Thus, animal models for carcinogenesis have proven to be important tools for the analysis of nodules and cancer progression (22). The resistant hepatocyte model (RHM) consistently reproduces the development of hepatocellular carcinoma (HCC) in male rats (23-25). The hepatic chemocarcinogenesis induced in the rat share several morphological, biochemical and molecular characteristics with human $\operatorname{HCC}(21,26)$. Since neoplastic pathology is a complex process, it has been divided into three phases: initiation (exposure to a carcinogen), promotion (initiated cell growth and the formation of altered cell foci) and progression (establishment of preneoplastic lesions and futher dedifferentiation to tumors). These phases can be distinguished in the RHM $(20,24,25)$. A necrogenic dose of diethylnitrosamine induces DNA damage and oxidative stress in hepatocytes during cancer initiation. The initiated cells can be stimulated to develop into altered hepatocyte foci (AHF) and nodules by a proliferative stimulus that consists of the administration of carcinogen 2-acetylaminofluorene in combination with partial hepatectomy (promotion). The AHF accumulates genomic damage and altered genetic expression ultimately progressing into $\mathrm{HCC}$ without any additional treatment with the carcinogen (progression) $(20,24,25)$. In the present study, we investigated the time course expression of the three DNMTs and the methylation patterns of three tumor-related genes exploiting the synchronous development of preneoplastic lesions and tumors in the RHM. We analyzed the methylation of timp3, rassfla and p16. It has been suggested that the downregulation of these genes enhances cancer development. Timp3 irreversibly inhibits metalloproteinases and is thought to be inactivated in cancer to facilitate metastasis (8). Rassfla inhibits cell proliferation by negatively regulating the G1/S-phase transition and enhances murine double minute 2 (MDM2) self-ubiquitination in response to DNA damage $(27,28)$. p16 is an inhibitor of cyclin D-dependent protein kinases, and its inactivation results in the cell being unable to halt the cell cycle in the G1 phase (28-30). These genes were also selected as they have been found to be frequently hypermethylated in several human and rat cancers, including $\operatorname{HCC}(7,8)$, and thus may be useful to determine whether methylation changes occurred in our model. The RHM exhibited a transient expression of the de novo DNMTs as part of the carcinogenic process. Our results also demonstrated that the RHM is a suitable model for the analysis of dynamic methylation changes.

\section{Materials and methods}

Animals and treatments. All the experiments followed the Institutional Animal Care and Use Committee Guidelines and the protocols were performed in accordance with and approved by the Comité Interno para el Cuidado y Uso de Animales de Laboratorio (CICUAL) of Cinvestav (Permit Number: 0001-02). Male F344 rats weighing 180-200 g (UPEAL-Cinvestav, Mexico, DF, Mexico) were subjected to a 10-day carcinogen treatment. The rats were initiated with an intraperitoneal dose of diethylnitrosamine $(200 \mathrm{mg} / \mathrm{kg})$. 2-Acetylaminofluorene was administered by gavage at a dose of $25 \mathrm{mg} / \mathrm{kg}$ during three consecutive days, beginning on day 7 after initiation. On day 10 , the rats were subjected to partial hepatectomy. The rats were fed with a germ-free diet and water ad libitum in a pathogen-free environment. The animals were housed in an air-ventilated room whose temperature was maintained at $24^{\circ} \mathrm{C}$ and a 12 -h light/dark cycle. Groups of 4-5 animals were sacrificed by exsanguination under ether anesthesia at different time periods from $24 \mathrm{~h}$ after initiation up to 12 months as described in Fig. 1. Livers were excised, washed in physiological saline solution, frozen in 2-methylbutane with liquid nitrogen and stored at $-70^{\circ} \mathrm{C}$.

Histological analysis. The putative preneoplastic lesions and tumors in rat livers were identified with the histoenzymatic staining of the $\gamma$-glutamil transpeptidase (GGT). Briefly, $4 \mu \mathrm{m}$ sections were cut from frozen liver tissue and mounted on poly-L-lysine-coated glass slides. The tissue sections were fixed in acetone for $5 \mathrm{~min}$ at $4^{\circ} \mathrm{C}$, followed by the addition of $0.3 \mathrm{mg} / \mathrm{ml} \alpha$-glutamyl-4-methoxy-2-naphthylamine, $2 \mathrm{mg} / \mathrm{ml}$ glycyl-glycine and $0.5 \mathrm{mg} / \mathrm{ml}$ Fast Blue BB salt in Tris base $(100 \mathrm{mM})$ solution for $10 \mathrm{~min}$ at room temperature. GGT-positive tissue was used as a guide to dissect preneoplastic lesions and tumors with a stainless steel cork borer (internal diameter, $1 \mathrm{~mm}$ ) from the frozen tissues. Separate slides were fixed and counterstained with hematoxylin and eosin (H\&E). Representative images were captured by optical microscopy (Olympus 1 70; Olympus Europa GmbH, Hamburg, Germany).

Methylation-specific PCR (MSP) and bisulfite sequencing $P C R$ (BSP). Genomic DNA purified from the liver of control and experimental animals underwent bisulfite modification according to the instructions for the EZ DNA Methylation kit (Zymo Research). MSP primers (M, methylated; U, unmethylated primers) were designed as previously reported (8). Products were amplified as follows: M-timp3 and U-timp3: 40 cycles at $94^{\circ} \mathrm{C}$ for $30 \mathrm{sec}, 57.5^{\circ} \mathrm{C}$ for $45 \mathrm{sec}$ and $72^{\circ} \mathrm{C}$ for $45 \mathrm{sec}$; M-rassfla: 40 cycles at $94^{\circ} \mathrm{C}$ for $30 \mathrm{sec}, 55^{\circ} \mathrm{C}$ for $45 \mathrm{sec}$ and $72^{\circ} \mathrm{C}$ for $45 \mathrm{sec}$; U-rassfla: 30 cycles at $94^{\circ} \mathrm{C}$ for $30 \mathrm{sec}, 50^{\circ} \mathrm{C}$ for $30 \mathrm{sec}$ and $72^{\circ} \mathrm{C}$ for $45 \mathrm{sec}$; M-p16 and U-p16: 40 cycles at $94^{\circ} \mathrm{C}$ for $30 \mathrm{sec}, 52.5^{\circ} \mathrm{C}$ for $30 \mathrm{sec}$ and $72^{\circ} \mathrm{C}$ for $45 \mathrm{sec}$; in all the cases, an initial denaturation step at $94^{\circ} \mathrm{C}$ for $10 \mathrm{~min}$ and final extension at $72^{\circ} \mathrm{C}$ for $10 \mathrm{~min}$ were included. Fully methylated genomes (positive controls) were obtained by the in vitro methylation of genomic DNA derived from non-treated rats with Sss1 methylase according to the manufacturer's instructions (New England Biolabs) and subsequent bisulfite conversion. BSP of timp3 was performed in a $20-\mu 1$ reaction mixture under the conditions: initial denaturation at $94^{\circ} \mathrm{C}$ for 


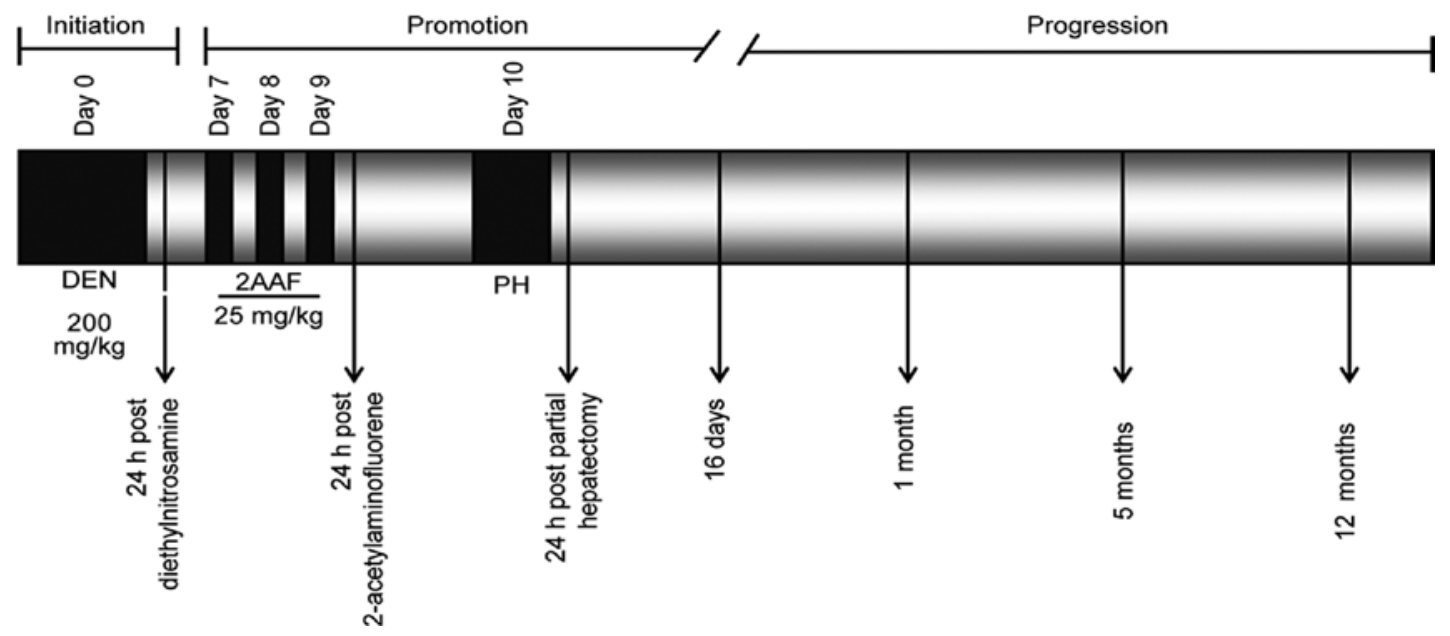

Figure 1. Schematic representation of the RHM model. Carcinogenic treatment was initiated with the administration of 200 mg/kg of diethylnitrosamine intraperitoneally. On days 7,8 and 9,25 mg/kg/day of 2-acetylaminofluorene was administered by gavage, and a partial hepatectomy was performed at day 10 . Groups of 5 rats were sacrificed at the times indicated at the black arrows. A group of 5 non-treated rats (NT) were sacrificed at 12 months and used as controls. The stages of carcinogenesis, i.e., initiation, promotion and progression, are also shown.

$10 \mathrm{~min} ; 40$ cycles at $94^{\circ} \mathrm{C}$ for $30 \mathrm{sec}, 60^{\circ} \mathrm{C}$ for $45 \mathrm{sec}$, and $72^{\circ} \mathrm{C}$ for $45 \mathrm{sec}$; and a final extension at $72^{\circ} \mathrm{C}$ for $10 \mathrm{~min}$. The primer sequence for timp3 (GenBank: AC136645) BSP was: sense: 5'-AAGGGGAAATTTTTTTTGAGGTTTT-3' and antisense: 5'-CCCCTCTAACCAATAACAACCC-3'. Amplified products were visualized by $2 \%$ agarose gel electrophoresis. PCR amplicons were purified using isopropanol precipitation and then sequenced in reverse direction, from at least three independent amplification products. Purified DNA was diluted and cycle-sequenced using the ABI BigDye Terminator kit v3.1 (Applied Biosystems, Foster City, CA, USA) according to the manufacturer's instructions. Sequencing reactions were electrophoresed on an ABI3100 genetic analyzer.Electropherograms were analyzed for the presence of methylated or unmethylated CpG islands. The set of primers were designed by using Methyl Primer Express v1.0 software (Life Technologies Corp.). The $\mathrm{CpG}$ islands were verified using the Methyl Primer Express v1.0 software (GC percentage $<55 \%$, observed-to-expected $\mathrm{CpG}$ ratio $<65 \%$ ).

Semi-quantitative RT-PCR. RNA was extracted from frozen liver tissue using TriPure Isolation reagent according to the manufacturer's instructions (Roche). cDNA synthesis and PCR were performed in One Step (SuperScript One-Step RT-PCR; Invitrogen). Appropriate primers (0.2 mM each) and $150 \mathrm{ng}$ of total RNA per $20 \mu \mathrm{l}$ of reaction were used. The absence of DNA contamination was verified by PCR assay. The cycling parameters used were: $45 \mathrm{~min}$ at $45^{\circ} \mathrm{C}$ for cDNA synthesis, followed by $2 \mathrm{~min}$ at $94^{\circ} \mathrm{C}$; denaturing for $15 \mathrm{sec}$ at $94^{\circ} \mathrm{C}$, annealing for $30 \mathrm{sec}$ between $50^{\circ} \mathrm{C}$ and $55^{\circ} \mathrm{C}$, followed by $30 \mathrm{sec}$ at $72^{\circ} \mathrm{C}$; and final elongation for $10 \mathrm{~min}$ at $72^{\circ} \mathrm{C}$. An adequate number of cycles corresponding to exponential amplification were performed to avoid saturated products with a kinetic analysis of 20-35 cycles for each gene. Primer set sequences were: for timp3 (GenBank: NM_012886): sense, 5'-GCGTGTATGAAGGCAAGATG-3' and antisense, 5'-GGT CACAAAGCAAGGCAAGT-3'; for rassfla (GenBank: NM_001037555): sense, 5'-CCGCACCTCTTTTTACTT GC-3' and antisense, 5'-GGCGTTCAGTTCGTTCAAA-3'; for pl6 (GenBank: NM_031550): sense, 5'-TACCCCGATACAG GTGATGA-3' and antisense, 5'-TCGTGATGTCCCCGCTC TA-3'; for dnmt1 (GenBank: NM_053354) sense, 5'-CGGAT TGGTCGGATAAAAGA-3' and antisense, 5'-GCTTCCTCA TCGCTCCAGTA-3'; for dnmt3a (GenBank: NM_001003958): sense, 5'-GGAGAGGAAAGGGAGAGAGG-3' and antisense, 5'-AGGGATGGTGCTGTTGAGAC-3'; for dnmt3b (GenBank: NM_031144): sense, 5'-AAACCCAACAACAAGCAACC-3' and antisense, 5'-ACATCAGAAGCCATCCGTTC-3'; and for $\beta$-actin (GenBank: NM_031144): sense, 5'-CCTCTATGCCAA CACAGTGC-3' and antisense, 5'-CATCGTACTCCTGCTTG CTG-3'.

Immunohistochemical staining. Tissue sections $(4 \mu \mathrm{m})$ mounted on poly-L-lysine-coated glass slides were obtained as previously described. Briefly, the frozen tissue sections were fixed in a $0.2 \%$ glutaraldehyde solution (31). Endogeneous peroxidase activity was blocked by incubating sections with $3 \% \mathrm{H}_{2} \mathrm{O}_{2}$. Following treatment with $1 \%$ bovine albumin for $10 \mathrm{~min}$ to block non-specific protein binding sites, rabbit polyclonal antibodies for DNMT1 (sc-20701, dilution 1:25; Santa Cruz Biotechnology, Inc., Santa Cruz, CA, USA), DNMT3a (sc-20703, dilution 1:25; Santa Cruz Biotechnology, Inc.) and DNMT3b (sc-20704, dilution 1:25; Santa Cruz Biotechnology, Inc.) were incubated overnight at $4^{\circ} \mathrm{C}$. Antigen-antibody complexes were visualized using standard staining protocol (LSAB Plus-Kit; Dako). Slides were counterstained with methyl green for $1 \mathrm{~h}$ to visualize nuclei. Representative images were captured by optical microscopy (Olympus 170; Olympus Europa $\mathrm{GmbH}$ ).

Statistical analysis. The experiments were repeated at least three times. Results are reported as means \pm SEM. Statistical significance was determined using t-test with $\mathrm{P}<0.05$ as the level of significance. Statistical analysis was performed using Prism 4 (GraphPad Software, La Jolla, CA, USA). In order to quantify the methylation changes in the BSP, values of $1,0.5$ and 0 were assigned to a methylated cytosine, hemimethylated and unmethylated cytosine, respectively, and a 
A
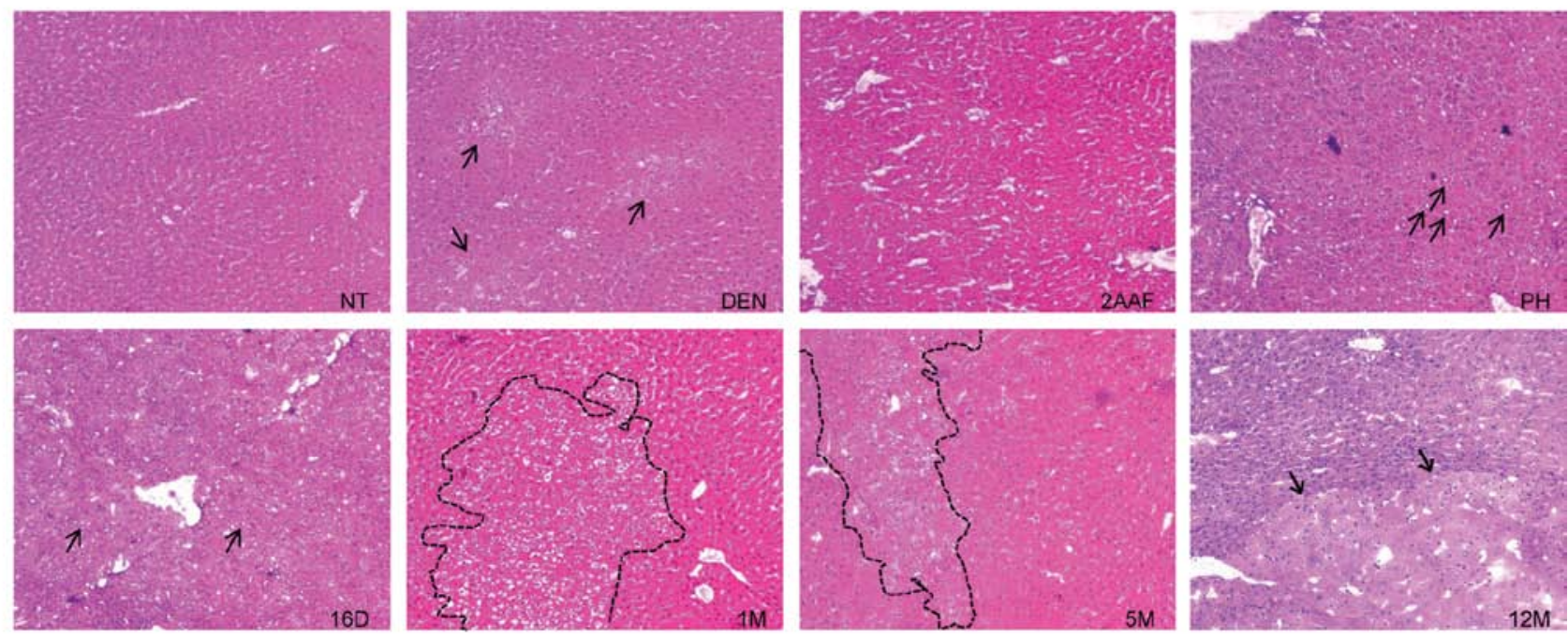

B
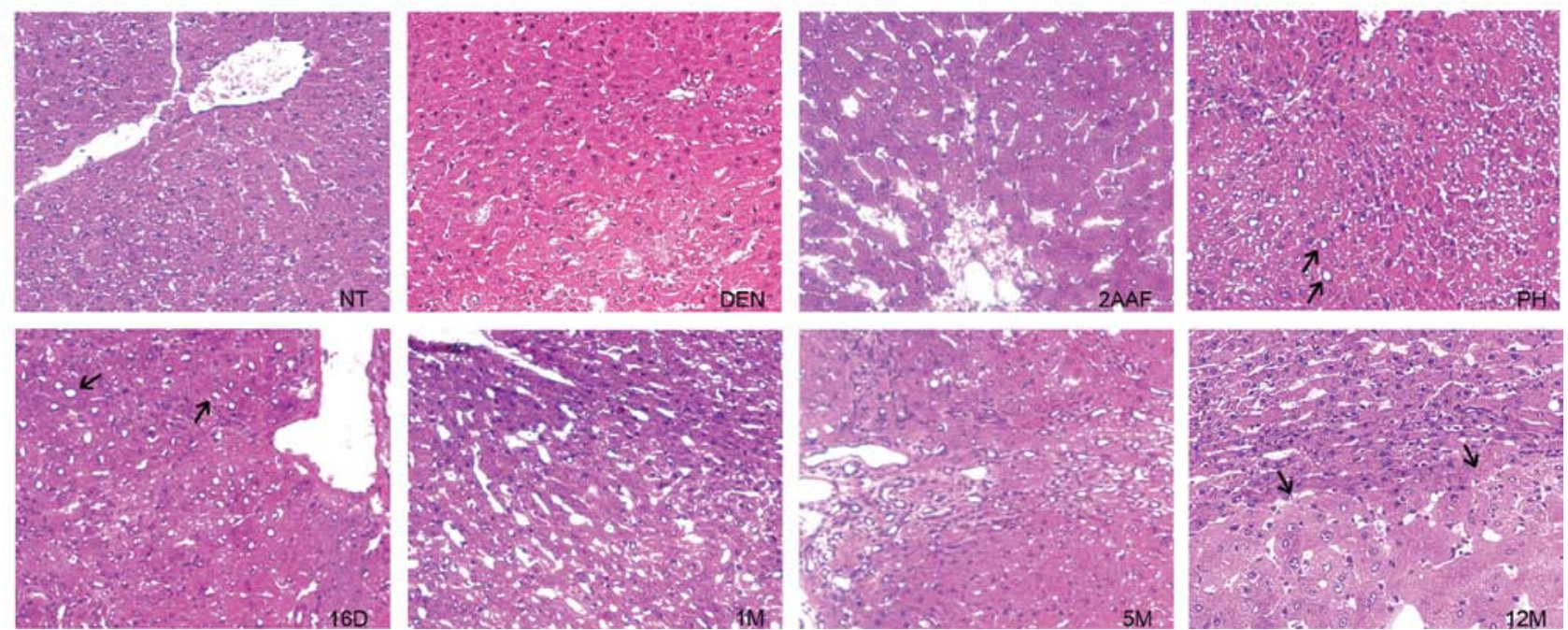

Figure 2. Preneoplastic lesions and tumors formation. (A) Representative histological sections from the livers of rats sacrificed $24 \mathrm{~h}$ after administration of diethylnitrosamine (DEN), $24 \mathrm{~h}$ after administration of 2-acetylaminofluorene (2AAF), $24 \mathrm{~h}$ after partial hepatectomy (PH); and 16 days (16D), $1 \mathrm{month}(1 \mathrm{M})$, 5 months $(5 \mathrm{M})$ and 12 months (12M) after complete carcinogenic treatment. Arrows in DEN show necrotic areas. Arrows in PH and 16D show cells with nuclear atypia. Preneoplastic lesions are evident in $1 \mathrm{M}$ and 5M, as the area inside the dashed line. Tumors were detected in 12M (arrows). Non-treated (NT) shows the normal architecture of the rat hepatic tissue. All images are shown with a magnification of 10. (B) Representative histological sections shown with a magnification of x20. A necrotic area is visible at the bottom of DEN, while cells with nuclear atypia are indicated by the arrows in PH and 16D. Preneoplastic lesions are shown in $1 \mathrm{M}$ and $5 \mathrm{M}$. Arrows indicate the tumor cells evident at the bottom of $12 \mathrm{M}$.

multinomial distribution analysis was performed. Briefly, the sum (according to the values assigned) and the distribution of three possible states (methylated, hemimethylated and unmethylated) in the treated groups were compared against the non-treated samples. Statistical significance was determined when the P-value was $<0.05$ (Computer Software Microsoft Excel; Microsoft Redmond, WA, USA).

\section{Results}

Preneoplastic lesions and tumor detection. The hepatic tissue throughout the RHM was analyzed. Changes in the morphology of the liver due to the carcinogenic treatment, including necrosis, was detected $24 \mathrm{~h}$ after diethylnitrosamine administration by H\&E staining. Hepatocytes with nuclear atypia were initially observed $24 \mathrm{~h}$ after 2 -acetylaminofluorene administration, and persisted $24 \mathrm{~h}$ after partial hepatectomy and 16 days after complete treatment, but disappeared at
1 month. Hepatocyte nodules and tumor lesions were identified by H\&E staining (Fig. 2) and by determining the presence of the GGT marker (Fig. 3). Numerous nodules were uniformly stained for GGT activity at 1 month. These nodules contained hepatocytes with minimal nuclear atypia. The number of nodules decreased from 1 to 5 months, which is associated with the presence of remodeling and persistent nodules, as described by Enomoto and Farber (32). HCC were found after 12 months. These lesions exhibited increased cytoplasmic size of hepatocytes, nuclear atypia, and anisonucleosis (Fig. 2).

DNA methylation changes of timp3, rassfla and p16. To assess whether our rat model had an aberrant DNA methylation pattern, the methylation status of the tumor-related genes was analyzed by MSP. Products from non-treated samples (NT) were only amplified with the unmethylated primers (U). timp3 and rassfla were amplified with the methylated (M) primers in the majority of the samples, while p16 showed consistent 

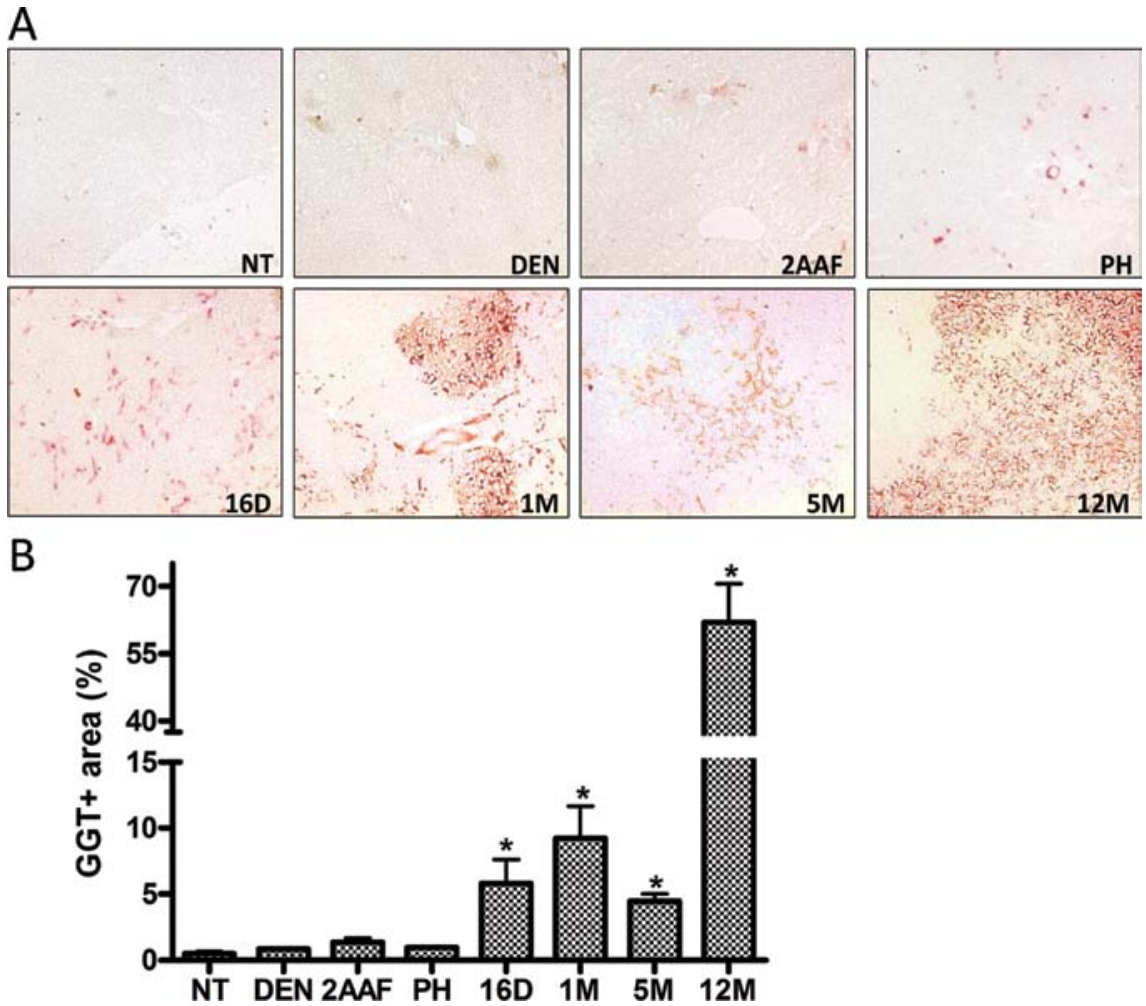

Figure 3. Preneoplastic lesions and tumors identified by GGT activity. (A) Representative histological sections from the livers of non-treated rats (NT) and rats sacrificed $24 \mathrm{~h}$ after administration of DEN (DEN), $24 \mathrm{~h}$ after administration of 2-AAF (2AAF), $24 \mathrm{~h}$ after partial hepatectomy (PH); and 16 days (16D), 1 month (1M), 5 months $(5 \mathrm{M})$ and 12 months (12M) after complete carcinogenic treatment. Images are shown at a magnification of x10. (B) Percentage of positive GGT area in NT-non treated rats, DEN, $24 \mathrm{~h}$ after administration of DEN; 2AAF, $24 \mathrm{~h}$ after the last administration of 2-AAF (2AAF); PH, $24 \mathrm{~h}$ after partial hepatectomy; and 16D, 16 days; 1M, 1 month; 5M, 5 months; and 12M, 12 months after complete carcinogenic treatment, respectively. Data were obtained from three independent experiments with the quantification of 5 fields at $x 10$ each, and are expressed as the means \pm SEM. Samples were statistically significant when ${ }^{*} \mathrm{P}<0.05$.

Table I. M and U amplification frequency in three independent experiments.

\begin{tabular}{|c|c|c|c|c|c|c|c|c|}
\hline Gene names & NT & DEN & $2 \mathrm{AAF}$ & $\mathrm{PH}$ & $16 \mathrm{D}$ & $1 \mathrm{M}$ & $5 \mathrm{M}$ & $12 \mathrm{M}$ \\
\hline M-timp3 & $0 / 3$ & $3 / 3$ & $3 / 3$ & $3 / 3$ & $3 / 3$ & $3 / 3$ & $3 / 3$ & $3 / 3$ \\
\hline U-timp3 & $3 / 3$ & $3 / 3$ & $3 / 3$ & $2 / 3$ & $2 / 3$ & $3 / 3$ & $3 / 3$ & $3 / 3$ \\
\hline M-rassfla & $0 / 3$ & $2 / 3$ & $3 / 3$ & $3 / 3$ & $2 / 3$ & $2 / 3$ & $3 / 3$ & $3 / 3$ \\
\hline U-rassfla & $3 / 3$ & $3 / 3$ & $3 / 3$ & $3 / 3$ & $2 / 3$ & $3 / 3$ & $3 / 3$ & $3 / 3$ \\
\hline M-p16 & $0 / 3$ & $1 / 3$ & $1 / 3$ & $1 / 3$ & $1 / 3$ & $2 / 3$ & $0 / 3$ & $3 / 3$ \\
\hline $\mathrm{U}-p 16$ & $3 / 3$ & $3 / 3$ & $3 / 3$ & $3 / 3$ & $3 / 3$ & $3 / 3$ & $3 / 3$ & $3 / 3$ \\
\hline
\end{tabular}

NT, non-treated rats; DEN, $24 \mathrm{~h}$ after administration of DEN; 2AAF, $24 \mathrm{~h}$ after the last administration of 2-AAF (2AAF); PH, $24 \mathrm{~h}$ after partial hepatectomy; 16D, 16 days; 1M, 1 month; 5M, 5 months; and 12M, 12 months after complete carcinogenic treatment, respectively. $\mathrm{M}$, methylated; U, unmethylated.

amplification only at 12 months (Fig. 4B and Table I). The expression level of the three genes was investigated for differential mRNA expression. As expected, the mRNA of the three tumor suppressors decreased as the carcinogenic process was enhanced. timp3 and p16 expression showed a decrease in rats sacrificed 16 days after complete treatment and remained underexpressed in later stages. The subexpression of rassfla was statistically significant in $12 \mathrm{M}$ (Fig. 4C and D). To gain a quantitative understanding of the methylation changes seen in the MSP we performed BSP of timp3. The methylation level observed in treated rats gradually decreased when compared to NT (Fig. 4E). Few CpGs remained methylated at 5 months. However, the methylation increased at 12 months. Of note, the first, second, fourth and sixth CpGs appeared to be consistently methylated in tumors. The methylation of $\mathrm{CpGs}$ 9-13 also occurred more frequently in tumors than in normal samples (Fig. 4E).

Expression of DNMT1, DNMT3a and DNMT3b during the RHM model. After confirming that the DNA methylation is considerably modified in our rat model, the RNA and protein expression of the three DNMTs was analyzed. Fig. 5 shows 


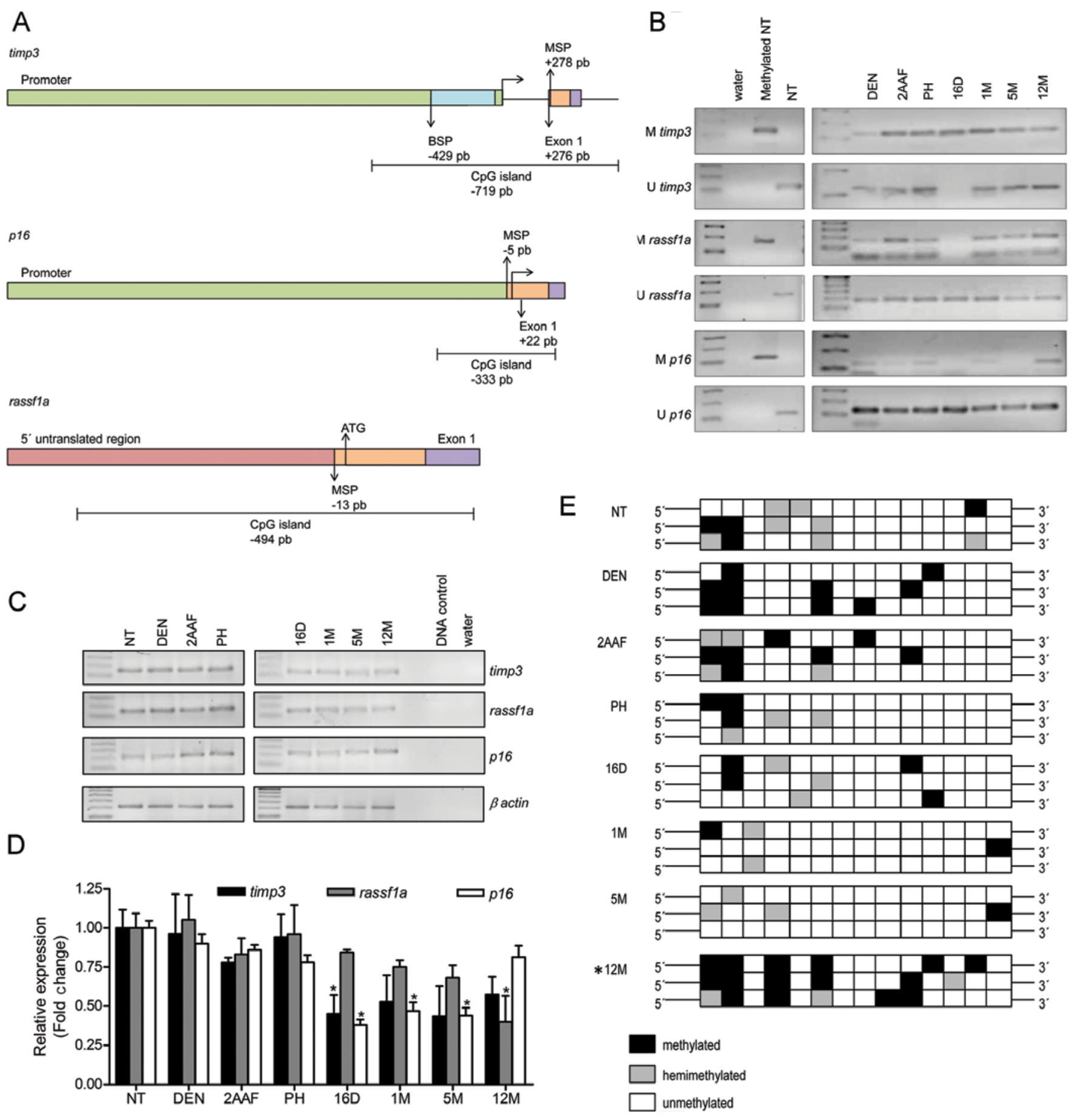

Figure 4. Methylation status of tumor-suppressor genes. (A) Schematic diagram of the fragments analyzed by MSP and BSP. The horizontal arrow shows the transcription start site. In timp 3 , the green box shows the promoter encompassing $2832 \mathrm{bp}$, the purple box is exon 1 and includes $178 \mathrm{bp}$ and the orange box is the MSP amplified region (120 bp). The fragment analyzed in the BSP is shown as the blue box (373 bp). In p16 (GenBank: AC_000073), the green box shows the promoter comprising $1408 \mathrm{bp}$, the purple box is exon 1 and spans $126 \mathrm{bp}$ and the orange box represents the MSP amplified region (123 bp). In rassfla (GenBank: NW_047801), the first translated codon is shown as ATG. The pink box shows the 5' untranslated region comprising 629 bp, the purple box is exon 1 and spans $250 \mathrm{bp}$ and the orange box is the MSP amplified region (169 bp). (B) MSP results of tumor-related genes timp3, rassfla and p16 $24 \mathrm{~h}$ after administration of diethylnitrosamine (DEN), 2-acetylaminofluorene (2AAF), partial hepatectomy (PH) and 16 days (16D), 1 month (1M), 5 and 12 months (5M and $12 \mathrm{M}$, respectively) after complete carcinogenic treatment are shown. Non-treated rat genomic DNA (NT), water and genomic DNA in vitro methylated by Sss1 were used as controls. (C) Expression of timp3, rassfla and p16 as determined by semi-quantitative RT-PCR. The expression level of $\beta$-actin was used to confirm the quality and quantity of total RNA from each sample. (D) Quantification of the expression of three tumor suppressor genes relative to NT. Data were obtained from three independent experiments and are expressed as the means \pm SEM. Results were statistically significant when "P<0.05. (E) Overview of bisulfite sequencing. Each box represents one sequenced $\mathrm{CpG}$ whose methylation status is indicated by coloration. Results were statistically significant when ${ }^{*} \mathrm{P}<0.05$, as described in Materials and methods.

the representative mRNA expression of the DNMTs across different stages of the RHM. dnmt1 was mildly subexpressed during carcinogen administration, but significantly overexpressed in the 12-month samples. dnmt3a and dnmt3b were also subexpressed during carcinogen administration and peaked at 16 days post-treatment. The two de novo 

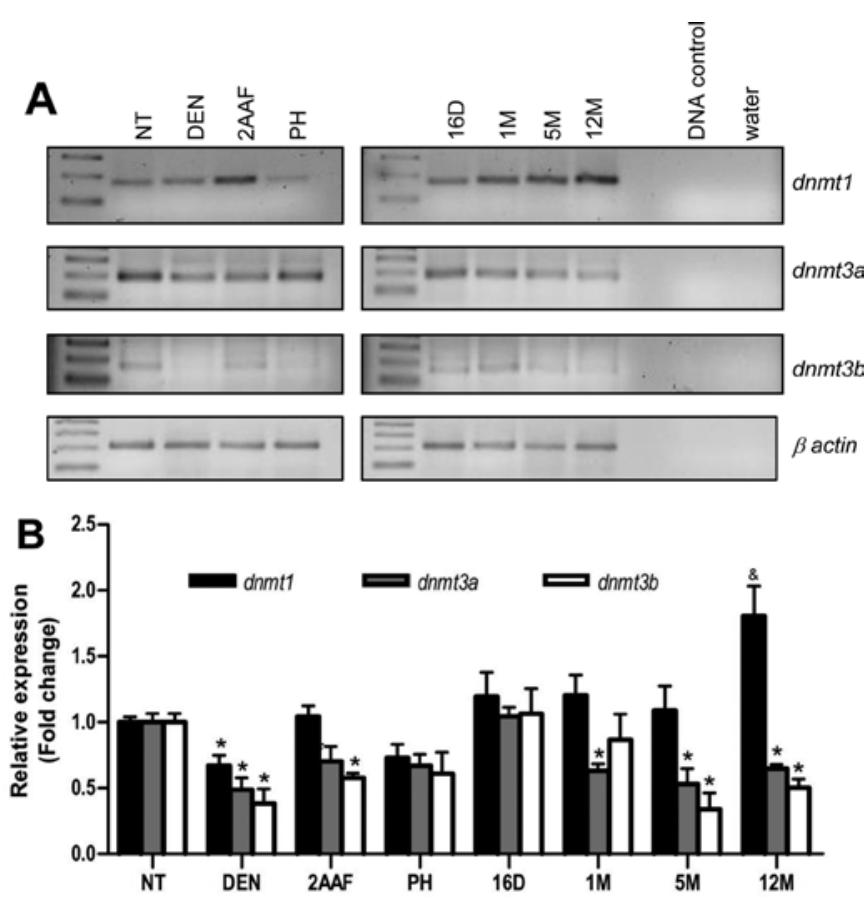

Figure 5. dnmts RNA expression in the RHM. (A) Expression of dnmt1, $d n m t 3 a$ and $d n m t 3 b$ were determined by semi-quantitative RT-PCR. The expression level of $\beta$-actin was used to confirm the quality and quantity of total RNA from each sample. Water and a reaction without reverse transcriptase (DNA control) were used as controls. (B) Quantification of the dnmts expression relative to NT. Data were obtained from three independent experiments and are expressed as the means \pm SEM. Subexpression was statistically significant when ${ }^{*} \mathrm{P}<0.05$, whereas overexpression was statistically significant when ${ }^{\circledR} \mathrm{P}<0.05$

Table II. Multinomial distribution analysis of the timp3 promoter methylation.

Variables

\begin{tabular}{ll}
\hline $\mathrm{NT}$ & 0.49428037 \\
$\mathrm{DEN}$ & 0.39282388 \\
$2 \mathrm{AAF}$ & 0.25557738 \\
$\mathrm{PH}$ & 0.8489242 \\
$16 \mathrm{D}$ & 0.8489242 \\
$1 \mathrm{M}$ & 0.94073454 \\
$5 \mathrm{M}$ & 0.9857591 \\
$12 \mathrm{M}$ & $0.0192686^{\mathrm{a}}$ \\
\hline
\end{tabular}

NT, non-treated rats; DEN, $24 \mathrm{~h}$ after administration of DEN; 2AAF, $24 \mathrm{~h}$ after the last administration of 2-AAF (2AAF); PH, $24 \mathrm{~h}$ after partial hepatectomy; 16D, 16 days; $1 \mathrm{M}, 1$ month; 5M, 5 months; and $12 \mathrm{M}, 12$ months after complete carcinogenic treatment, respectively. The accumulated probability was calculated using the sum and the distribution of three possible states (methylated, hemimethylated and unmethylated). Results were statistically significant when ${ }^{*} \mathrm{P}<0.05$.

methyltransferases were subexpressed in preneoplastic lesions and tumors (Fig. 5). Immunohistochemical staining patterns of the DNMTs were obtained to support the results of the semi-quantitative RT-PCR. Only DNMT1 nuclear immunostaining was positive and evenly distributed in normal tissue
(Fig. 6A). A slight decrease in the DNMT1 nuclear intensity was observed $24 \mathrm{~h}$ after diethylnitrosamine and 2-acetylaminofluorene administration, whereas DNMT3a and DNMT3b were positive $24 \mathrm{~h}$ after diethylnitrosamine exposure. While the nuclear signal of DNMT1 was sustained between $24 \mathrm{~h}$ after partial hepatectomy, 16 days post-treatment, and the first and fifth months (Figs. 6A and 7A), DNMT3a and DNMT3b expression was decreased and could not be detected in the preneoplastic lesions (first and fifth months) (Fig. 6B and $\mathrm{C}$, respectively). Tumor cells at 12 months exhibited an increased nuclear size with DNMT1-positive expression in the periphery of the nucleus. Nevertheless, no significant overexpression was evident at 12 months (Fig. 6A and 7A). In accordance with the semi-quantitative RT-PCR, DNMT3a and DNMT3b were again negative in the tumor samples.

\section{Discussion}

Animal models of hepatocarcinogenesis have provided reliable data for understanding the cellular development of human HCC. The RHM is characterized by the evolution from nodules to HCC without additional carcinogen treatment, mirroring the three main stages of carcinogenesis: initiation, promotion and progression (20,23-26). It may be hypothesized that any epigenetic changes detected following carcinogen administration can be related to the development of cancer and not to the carcinogen itself.

Aberrant DNA methylation is a frequent epigenetic event in cancer and it has been established that it depends upon the overexpression of the DNMTs. However, it has been difficult to track the methylation changes and the expression of DNMTs during the different stages of carcinogenesis. Therefore, we examined the expression of the DNMTs in the RHM. First, we confirmed that the methylation status of tumor-suppressor genes was affected as described previously $(7,8)$. The MSP indicated that DNA methylation for timp3 and rassfla occurred after carcinogen administration, while p16 only appeared consistently methylated in tumors. It was also found that the expression of the three tumor suppressors declined after the complete carcinogenic treatment. Thus, future studies should focus on other mechanisms that may co-operate with DNA methylation to inactivate these tumor suppressors. BSP of timp3 was performed to gain a better understanding of the methylation changes observed in the MSP. The basal methylation level of the timp3 promoter was reduced during the formation of preneoplastic lesions but was regained in tumors (Fig. 4). In the MSP, the amplified region was designed to analyze $\mathrm{CpGs}$ that were included in the exon 1 of these genes (Fig. 4A) (8). We found that the analysis of the CpGs within the promoter had a greater impact on gene transcription $(1,5,16)$. Thus, the amplified region in the BSP incorporated CpGs within the promoter and not near exon 1 . Therefore, the discrepancies between the methylation status of timp3 in the MSP and the BSP were the result of differential methylation patterns of CpGs across the promoter and exon 1. Taking into consideration that the non-treated samples were not amplified with the ' $\mathrm{M}$ ' primers, the results show that timp3, rassfla and p16 were methylated due to the carcinogenic process. Furthermore, the CpGs within the promoter of timp3 exhibited a gradual demethylation that spanned months prior to being 

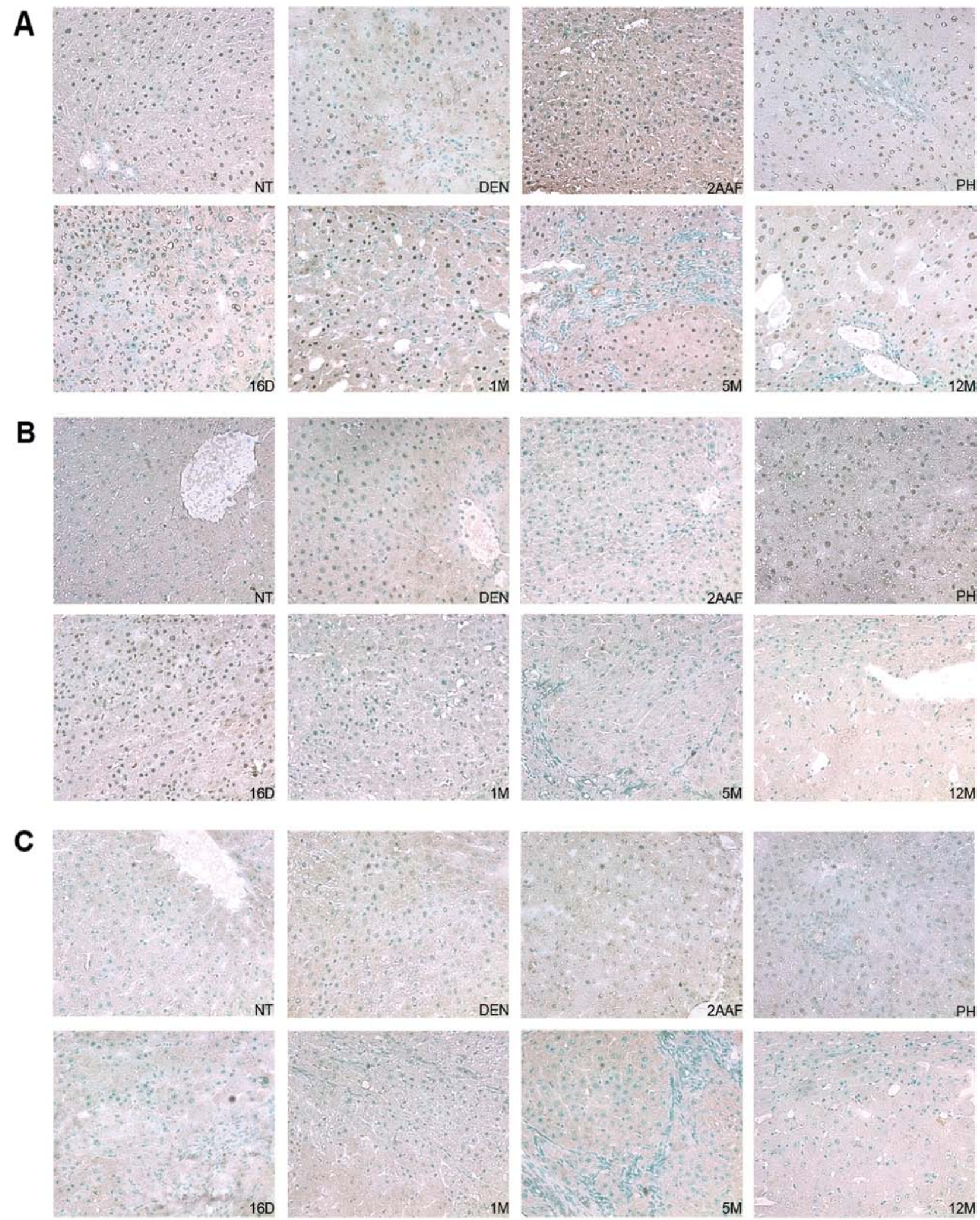

Figure 6. DNMTs nuclear localization by immunohistochemistry in the RHM model. (A) Representative histological sections from the livers of non-treated rats (NT) and rats sacrificed $24 \mathrm{~h}$ after administration of DEN (DEN), $24 \mathrm{~h}$ after administration of 2-AAF (2AAF), $24 \mathrm{~h}$ after partial hepatectomy (PH); 16 days (16D), 1 month (1M), 5 months (5M) and 12 months (12M) after complete carcinogenic treatment. Normal hepatocytes were positive for nuclear protein expression of DNMT1 (NT). DNMT1 showed an intense nuclear signal in the majority of the samples and was notably absent within the necrotic areas (DEN). (B) Representative histological sections from the livers of non-treated rats (NT) and rats sacrificed $24 \mathrm{~h}$ after administration of DEN (DEN), $24 \mathrm{~h}$ after administration of 2-AAF (2AAF), $24 \mathrm{~h}$ after partial hepatectomy (PH); and 16 days (16D), 1 month (1M), 5 months (5M) and 12 months (12M) after complete carcinogenic treatment. DNMT3a was detected at the early stages of the RHM (DEN, 2AAF, PH and 16D) before its nuclear expression was decreased at 1M, $5 \mathrm{M}$ and $12 \mathrm{M}$. (C) A) Representative histological sections from the livers of non-treated rats (NT) and rats sacrificed $24 \mathrm{~h}$ after administration of DEN (DEN), $24 \mathrm{~h}$ after administration of 2-AAF (2AAF), $24 \mathrm{~h}$ after partial hepatectomy (PH); and 16 days (16D), 1 month (1M), 5 months (5M) and 12 months (12M) after complete carcinogenic treatment. Positive nuclear signal for DNMT3b was weakly detected at the early stages of the RHM: DEN, 2AAF and PH prior to its nuclear expression being decreased at 16D, 1M, 5M and 12M. All the sections were counterstained with methyl green. Magnification, x20. 


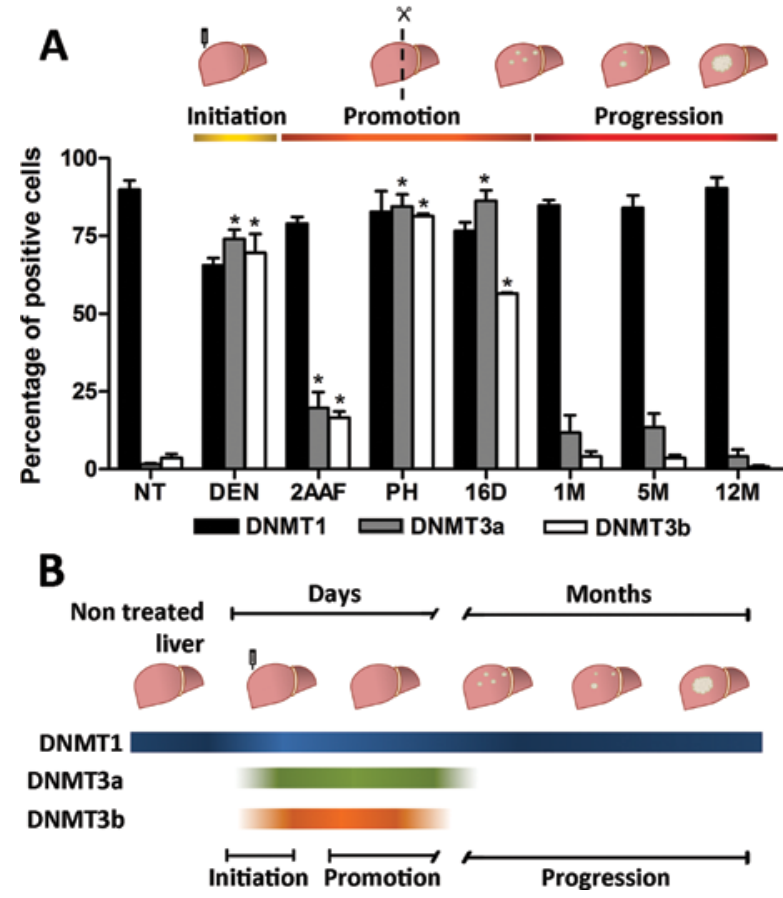

Figure 7. Quantitative examination of the DNMTs expression during initiation, promotion and progression. (A) Data were obtained from three independent experiments with the quantification of five fields at a magnification of $\mathrm{x} 10$ each, and are expressed as the means \pm SEM. Overexpression between treated vs. non-treated samples was statistically significant when ${ }^{*} \mathrm{P}<0.05$. (B) Schematic representation of the DNMTs expression during the stages of the RHM carcinogenesis. In non-treated livers, only the DNMT1 is detected. DNMT3a and DNMT3b were detected during the carcinogenic treatment, and remained present until 16 days post-treatment (initiation and promotion). Although the expression of DNMT1 decreased slightly during the carcinogenic exposure, it was the only enzyme evident in the preneoplastic lesions and tumors (progression).

hypermethylated in tumors (Fig. 4E and Table II). The results supported the subsequent analysis of the DNMTs.

The overexpression of the DNMTs has been reported in various types of cancer $(14,15)$. We found DNMT1 overexpressed at mRNA level in tumors. However, dnmt3a and $d n m t 3 b$ were decreased in preneoplastic lesions and tumors and these results were congruent with the immunohistochemical analysis. Although DNMT1 protein overexpression was not evident between normal hepatic tissue and preneoplastic lesions or tumors (Fig. 7A), we observed different nuclear immunoreactivity associated with the morphology of the nucleus (Fig. 6A). Notably, DNMT1 exhibited a diffuse nuclear signal in DEN samples which was also less intense than in NT. DNMT3a and DNMT3b, which were absent in non-treated samples, were localized similarly after diethylnitrosamine exposure. It was previously mentioned that diethylnitrosamine damages DNA and exacerbates hepatocyte oxidative stress in the RHM (22). Oxidative stress involves modifications in DNA bases, strand breaks, cross linkages, all of which increase mutational rates $(22,33)$ and it has been described that oxygen reactive species inhibit the methionine adenosyltransferases, responsible for supplying the DNMTs with the methyl donor, the s-adenosyl methionine (SAM) $(34,35)$. Thus, oxidative stress at the initiation of the model used in this study may hinder the availability of methyl donors. Thus, the diffuse nuclear localization following diethylnitrosamine administration may be associated with a low abundance of SAM. After partial hepatectomy and 16 days post-treatment, a positive expression of the DNMTs was detected, which peaked for DNMT3a and DNMT3b expression (Fig. 6B and C, respectively). It has been suggested that de novo methyltransferases are required for proper tissue regeneration in other animal models $(36,37)$. Thus, it is possible that DNMT3 was recruited as part of the hepatic regeneration between DEN and 16D. In spite of the downregulation of DNMT3a and DNMT3b, DNMT1 was still visible in preneoplastic lesions and tumors. Notably, at 12M DNMT1 was localized in the periphery of the nucleus. Hypermethylated regions have been found to co-localize with the nuclear lamina in human cell lines, colorectal cancer (38) and murine lung cancer models (16). Thus, the presence of DNMT1 at the edge of the nucleus corresponds to the hypermethylated regions near the nuclear lamina. During the time lapse between the fifth and twelfth months, the preneoplastic lesions dedifferentiated into tumors. At these stages, DNMT1 was the only enzyme present. However, if DNMT1 is important in the late dedifferentiation of tumors, the performance of the enzyme, when it is not overexpressed as described in other types of cancer remains to be determined. It is possible that specific protein interactions along post-translational modifications regulate DNMT1 performance and localization during the RHM. It has been reported that sumoylation of DNMT1 increases its catalytic activity (10). The phosphorylation of DNMT1 may be involved in conformational changes, enzyme stability and abundance of the enzyme in the replication bubbles and DNA repair sites $(39,40)$. However, a more or less active enzyme cannot account for the hypermethylation of specific genes in a hypomethylated background. We hypothesize that protein interactions allow the enzyme to identify its targets. DNMT1 is known to interact with proteins that assist its recruitment to replication sites (PCNA-proliferating cell nuclear antigen, URHF1-ubiquitin-like with PHD and RING finger domains 1) and with those that cooperate in gene silencing (pRB-retinoblastoma protein, HDAC1-histone deacetylase 1, HDAC2-histone deacetylase 2, EZH2-enhancer of zeste homologue 2) (41-43).

As discussed earlier, the RHM allows the analysis of the initiation, promotion and progression stages of carcinogenesis $(20,24,25)$. Although the de novo methyltransferases are downregulated in preneoplastic lesions and tumors, it is noteworthy that the two enzymes were detected in specific stages, i.e., after initiation and during promotion. Considering the literature available, the expression profile of the DNMT3s poses two scenarios: i) the enzymes may play an early role establishing methylation patterns that 'drive' cancer initiation and progression (1). When DNMT3s fulfill this role, they are downregulated as the DNMT1 copies the methylation patterns during subsequent cell replication (44). ii) The DNMT3s function as tumor supressors protecting cells from oncogene and transposable elements activation following demethylation $(16,45)$. As discussed earlier, after carcinogen administration a wave of oxidative stress ensues and oxygen reactive species enhance DNA hypomethylation $(22,34,35)$. Furthermore, Takasugi and colleagues (37) showed that DNA hypomethylation is induced by partial hepatectomy. Therefore, DNMT3a and DNMT3b may be required to prevent hypomethylation.

In summary, our MSP results indicate that timp3, rassfla and pl6 became methylated during and after complete 
carcinogenic treatment. Through BSP we found that a CpG-rich region within the promoter of timp3 first became hypomethylated in preneoplastic lesions and then hypermethylated in tumors. Although the RHM did not exhibit a statistically significant overexpression of DNMT1, it was the only enzyme detectable during the late dedifferentiation of preneoplastic lesions to tumors. By contrast, DNMT3a and DNMT3b were recruited specifically during initiation and promotion. To the best of our knowledge, this is the first report concerning the activation and subsequent downregulation of the de novo methyltransferases as part of the natural course of carcinogenesis in an animal model (Fig. 7B). The synchronous events evident in the RHM make it a suitable model to identify more specific functions and interactions of the DNMTs in shorter time windows in future studies; for example, to study the mechanisms involved in the genetic regulation of the DNMT3s by the end of the promotion stage and the protein interactions of the DNMT1 during the progression stage.

\section{Acknowledgements}

The authors would like to thank Samia Fattel, Leobardo García-Molina, Sergio Hernández-García, Julia Torres-Mena and Ruth Pacheco-Rivera for their technical support. They also thank Dr José de Jesús Serrano-Luna at CINVESTAV and Dr Julio Isael Pérez-Carreón at the Instituto Nacional de Medicina Genómica, for useful comments in the preparation of the manuscript. The present study was supported by the Multidisciplinary Project, CINVESTAV, by CONACyT, grant no. CB12-178558 and scholarship: 207267 and COMECYT scholarship: 13BTD0531.

\section{References}

1. Aryee MJ, Liu W, Engelmann JC, Nuhn P, Gurel M, Haffner MC, Esopi D, Irizarry RA, Getzenberg RH, Nelson WG, Luo J, Xu J, Isaacs WB, Bova GS and Yegnasubramanian S: DNA methylation alterations exhibit intra-individual stability and inter-individual heterogeneity in prostate cancer metastases. Sci Transl Med, doi: 10.1126/scitranslmed.3005211, 2013.

2. Jones PA and Baylin SB: The fundamental role of epigenetic events in cancer. Nat Rev Genet 3: 85-93, 2002.

3. Jones PA and Baylin SB: The epigenomics of cancer. Cell 128: 683-692, 2007.

4. Rishi V, Bhattacharya P, Chatterjee R, Rozenberg J, Zhao J, Glass K, Fitzgerald P and Vinson C: $\mathrm{CpG}$ methylation of half-CRE sequences creates $\mathrm{C} / \mathrm{EBP} \alpha$ binding sites that activate some tissuespecific genes. Proc Natl Acad Sci 107: 20311-20316, 2010.

5. Ziller MJ, Gu H, Müller F, Donaghey J, Tsai LT, Kohlbacher O, De Jager PL, Rosen ED, Bennett DA, Bernstein BE, Gnirke $A$ and Meissner A: Charting a dynamic DNA methylation landscape of the human genome. Nature 500: 477-481, 2013.

6. Cheng X and Blumenthal RM: Mammalian DNA methyltransferases: a structural perspective. Structure 3: 341-350, 2008.

7. Sigalotti L, Fratta E, Coral S, Cortini E, Covre A, Nicolay HJ, Anzalone L, Pezzani L, Di Giacomo A, Fonsatti E, Colizzi F, Altomonte M, Calabrò L and Maio M: Epigenetic drugs as pleiotropic agents in cancer treatment: biomolecular aspects and clinical applications. J Cell Physiol 212: 330-344, 2007.

8. Asada K, Asada R, Yoshiji H, Fukui H, Floyd RA and Kotake Y: DNA cytosine methylation profile in various cancer-related genes is altered in cultured rat hepatocyte cell lines as compared with primary hepatocytes. Oncol Rep 15: 1241-1248, 2006.

9. Feinberg AP and Vogelstein B: Hypomethylation distinguishes genes of some human cancers from their normal counterparts. Nature 301: 89-92, 1983.

10. Lee B and Muller MT: SUMOylation enhances DNA methyltransferase 1 activity. Biochem J 421: 449-461, 2009.
11. Ling Y, Sankpal UT, Robertson AK, McNally JG, Karpova T and Robertson KD: Modification of de novo DNA methyltransferase 3a (Dnmt3a) by SUMO-1 modulates its interaction with histone deacetylases (HDACs) and its capacity to repress transcription. Nucleic Acids Res 32: 598-610, 2004.

12. Kanai Y and Hiroshida S: Alterations of DNA methylation associated with abnormalities of DNA methyltransferases in human cancers during transition from a precancerous to a malignant state. Carcinogenesis 28: 2434-2442, 2007.

13. Oh BK, Kim H, Park HJ, Shim YH, Choi J, Park C and Park YN: DNA methyltransferase expression and DNA methylation in human hepatocellular carcinoma and their clinicopathological correlation. Int J Mol Med 20: 65-73, 2007.

14. Choi MS, Shim YH, Hwa JY, Lee SK, Ro JY, Kim JS and Yu E: Expression of DNA methyltransferases in multistep hepatocarcinogenesis. Hum Pathol 34: 11-18, 2013.

15. Yoshimasa S, Yae K, Tohru N, Michiie S, Hidetsugu S, Hiromasa I and Setsuo H: Increased protein expression of DNA methyltransferase (DNMT) 1 is significantly correlated with the malignant potential and poor prognosis of human hepatocellular carcinomas. Int J Cancer 105: 527-532, 2003.

16. Raddatz G, Gao Q, Bender S, Jaenisch R and Lyko F: Dnmt3a protects active chromosome domains against cancer-associated hypomethylation. PLoS Genet 8: e1003146, 2012.

17. Yan XJ, Xu J, Gu ZH, Pan CM, Lu G, Shen Y, Shi JY, Zhu YM, Tang L, Zhang XW, Liang WX, Mi JQ, Song HD, Li KQ, Chen Z and Chen SJ: Exome sequencing identifies somatic mutations of DNA methyltransferase gene DNMT3A in acute monocytic leukemia. Nat Genet 43: 309-315, 2011.

18. Hlady RA, Novakova S, Opavska J, Klinkebiel D, Peters LS, Bies J, Hannah J, Iqbal J, Anderson KM, Siebler HM, Smith LM, Greiner TC, Bastola D, Joshi S, Lockridge O, Simpson MA, Felsher DW, Wagner KU, Chan WC, Christman JK and Opavsky R: Loss of Dnmt3b function upregulates the tumor modifier Ment and accelerates mouse lymphomagenesis. J Clin Invest 122: 163-177, 2012.

19. Trinh BN, Long TI, Nickel AE, Shibata D and Laird PW: DNA methyltransferase deficiency modifies cancer susceptibility in mice lacking DNA mismatch repair. Mol Cell Biol 22: 2906-2917, 2002.

20. Pérez-Carreón JI, López-García C, Fattel-Fazenda S, Arce-Popoca E, Alemán-Lazarini L, Hernández-García S, Le Berrey V, Sokoly S, Francoisy JM and Villa-Treviño S: Gene expression profile related to the progresión of preneoplastic nodules toward hepatocellular carcinoma in rats. Neoplasia 8: 373-383, 2006.

21. Rotstein J, Macdonald PD, Rabes HM and Farber E: Cell cycle kinetics of rat hepatocytes in early putative preneoplastic lesions in hepatocarcinogenesis. Cancer Res 44: 2913-2917, 1984.

22. Sánchez-Pérez Y, Carrasco-Legleu C, García-Cuellar C, Pérez-Carreón JI, Hernández-García S, Salcido-Neyoy M, Alemán-Lazarini L and Villa-Treviño S: Oxidative stress in carcinogenesis. Correlation between lipid peroxidation and induction of preneoplastic lesions in rat hepatocarcinogenesis. Cancer Lett 217: 25-32, 2005.

23. Solt D and Farber E: New principle for the analysis of chemical carcinogenesis. Nature 263: 701-703, 1976.

24. Solt DB, Medine A and Farber E: Rapid emergence of carcinogen-induced hyperplastic lesions in a new model for the sequential analysis of liver carcinogenesis. Am J Pathol 88: 595-618, 1977.

25. Solt DB, Cayama E, Tsuda H, Enomoto K, Lee G and Farber E: Promotion of liver cancer development by brief exposure to dietary 2-acetylaminofluorene plus partial hepatectomy or carbon tetrachloride. Cancer Res 43: 188-191, 1983.

26. Pascale RM, Simile MM, De Miglio MR, Muroni MR, Calvisi DF, Asara G, Casabona D, Frau M, Seddaiu MA and Feo F: Cell cycle deregulation in liver lesions of rats with and without genetic predisposition to hepatocarcinogenesis. Hepatology 35: 1341-1350, 2002.

27. Wen BL, Ao L, Zhou ZY, Cui ZH, Zhou YH, Yuan XY, Xiang YL, Cao J and Liu JY: CpG island hypermethylation of multiple tumor suppressor genes associated with loss of their protein expression during rat lung carcinogenesis induced by 3-methylcholanthrene and diethylnitrosamine. Biochem Biophys Res Commun 402: 507-514, 2010.

28. Agathanggelou A, Cooper WN and Latif F: Role of the Ras-association domain family 1 tumor suppressor gene in human cancers. Cancer Res 65: 3497-3508, 2005. 
29. Du YP, Peng JS, Sun A, Tang ZH, Ling WH and Zhu HL: Assessment of the effect of betaine on p16 and $c$-myc DNA methylation and mRNA expression in a chemical induced rat liver cancer model. BMC Cancer doi: 10.1186/1471-2407-9-261, 2009.

30. Li J, Knobloch TJ, Poi MJ, Zhang Z, Davis AT, Muscarella P and Weghorst CM: Genetic alterations of RD ${ }^{\mathrm{INK} 4 / \mathrm{ARF}}$ enhancer in human cancer cells. Mol Carcinog 53: 211-218, 2014.

31. Gutierrez-Reyes G, del Carmen Garcia de Leon M, VarelaFascinetto G, Valencia P, Pérez Tamayo R, Rosado CG, Labonne BF, Rochilin NM, Garcia RM, Valadez JA, Latour GT, Corona DL, Diaz GR, Zlotnik A and Kershenobich D: Cellular senescence in livers from children with end stage liver disease. PLoS One 5: e10231, 2010.

32. Enomoto K and Farber E: Kinetics of phenotypic maturation of remodeling of hyperplastic nodules during liver carcinogenesis. Cancer Res 42: 2330-2335, 1982.

33. Ziech D, Franco R, Pappa A and Panayiotidis MI: Reactive oxygen species (ROS) - induced genetic and epigenetic alterations in human carcinogenesis. Mutat Res 711: 167-173, 2011

34. Torres L, Avila MA, Carretero MV, Latasa MU, Caballería J, López-Rodas G, Boukaba A, Lu SC, Franco L and Mato JM: Liver-specific methionine adenosyltransferase MAT1A gene expression is associated with a specific pattern of promoter methylation and histone acetylation: implications for MAT1A silencing during transformation. FASEB J 14: 95-102, 2004.

35. Yang H, Huang ZZ, Zeng Z, Chen C, Selby RR and Lu SC: Role of promoter methylation in increased methionine adenosyltransferase 2A expression in human liver cancer. Am J Physiol Gastrointest Liver Physiol 280: 184-190, 2001.

36. Takayama K, Shimoda N, Takanaga S, Hozumi S and Kikuchi Y: Expression patterns of dnmt $3 \mathrm{aa}, \mathrm{dnmt} 3 \mathrm{ab}$ and dnmt 4 during development and fin regeneration in zebrafish. Gene Expr Patterns 14: 105-110, 2014.

37. Takasugi M, Hayakawa K, Arai D and Shiota K: Age- and sexdependent DNA hypomethylation controlled by growth hormone in mouse liver. Mech Ageing Dev 134: 331-337, 2013.
38. Berman BP, Weisenberger DJ, Aman JF, Hinoue T, Ramjan Z, Liu Y,Noushmehr H,Lange CPE, M van Dijk C, Tollenaar RAEM, van den Berg D and Laird PW: Regions of focal DNA hypermethylation and long-range hypomethylation in colorectal cancer coincide with nuclear lamina-associated domains. Nat Genet 44: 40-46, 2012

39. Hervouet E, Lalier L, Debien D, Cheray M, Geairon A Rogniaux H, Loussouarn D, Martin S A, Vallette FM and Cartron PF: Disruption of Dnmt1/PCNA/UHRF1 interactions promotes tumorigenesis from human and mice glial cells. PLoS One 5: e11333, 2010

40. Mortusewicz O, Schermelleh L, Walter J, Cardoso MC and Leonhardt H: Recruitment of DNA methyltransferase I to DNA repair sites. Proc Natl Acad Sci 102: 8905-8909, 2005.

41. Gazin C, Wajapeyee N, Gobeil S, Virbasius CM and Green MR: An elaborate pathway required for Ras-mediated epigenetic silencing. Nature 449: 1073-1077, 2007.

42. Liu X, Gao Q, Li P, Zhao Q, Zhang J, Li J, Koseki H and Wong J: UHRF1 targets DNMT1 for DNA methylation through cooperative binding of hemi methylated DNA and methylated H3K9. Nat Commun doi: 10.1038/ncomms2562, 2013.

43. Shamma A, Suzuki M, Hayashi N, Kobayashi M, Sasaki N, Nihiuchi T, Doki Y, Okamoto T, Kohno S, Muranaka H, Kitajima S, Yamamoto K and Takahashi C: ATM mediates pRB function to control DNMT1 protein stability and DNA methylation. Mol Cell Biol 33: 3113-3124, 2013.

44. Cartron PF, Blanquart C, Hervouet E, Gregoire $M$ and Vallette FM: HDAC1-mSin3a-NCOR1, Dnmt3b-HDAC1-Egr1 and Dnmt1-PCNA-UHRF1-G9a regulate the NY-ESO1 gene expression. Mol Oncol 7: 452-463, 2013.

45. Xionga Y, Dowdya SC, Xueb A, Shujuana J, Eberhardtc NL, Podratza KC and Jianga SW: Opposite alterations of DNA methyltransferase gene expression in endometrioid and serous endometrial cancers. Gynecol Oncol 96: 601-609, 2005. 